\title{
Futility of Feminist Aspirations in Caryl Churchill's Top Girls: A Postfeminist Reading
}

\author{
Dr. Marwa Ramadan
}

Lecturer in English Literature

Faculty of Arts

Zagazig University

Abstract

Top Girls (1982) is a controversial play which calls Caryl Churchill's stance as a feminist into question. The present paper examines the play through the theoretical perspective of postfeminism, which advocates primary feminist goals but challenges some dominant feminist discourses, especially those pertaining to the binary structures of second-wave feminism. With its bleak delineation of the character of Marlene, the play explores the dangers of seeking women empowerment by espousing masculine qualities, adopting an anti-family attitude, and paying no heed to the suffering of fellow women. Investigating the polarization of characters based on their gender, race, class, or religion, and the dilemma of choosing between career success and family stability, the paper highlights the need for an egalitarian family-friendly feminism based on a real sense of sisterhood among women.

\section{Key words}

second-wave feminism, postfeminism, women empowerment, espousing/rejecting masculine qualities, Caryl Churchill, marginalized women, sisterhood 
Futility of Feminist Aspirations in Caryl Churchill's Top Girls: A

\section{Postfeminist Reading}

\section{إخفاق التطلعات النسوية في مسرحية "فتيات القمة" لكاريل \\ تشرشل: قراعة من منظور ما بعد النسوية

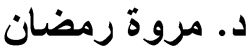 \\ مدرس الأدب الإنجليزي}

كلية الآداب

جامعة الزقازيق

ملخص البحث

تحتل كاريل تشرشل مكانة بارزة بين كتاب المسرح البريطاني المعاصر بما قدمته من

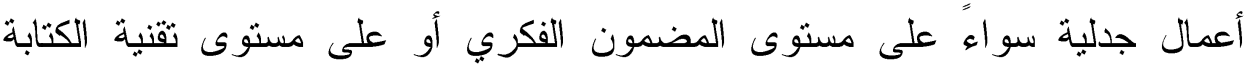
المسرحية، وتُعد مسرحيتها "فتنات القمة" (ب و 19) من أكثر هذه الأعمال إثارة للجدل

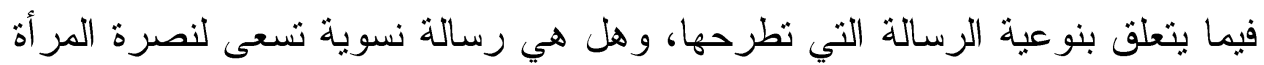

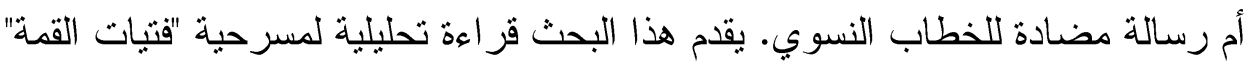
من منظور ما بعد النسوية التي تدعم الأهداف الأساسية للحركة النسائية ولكنها تدحض لمانس بعض الخطابات المهيمنة في الفكر النسوي، وخاصة تللك المتعلقة بالهياكل الثنائية للموجة النسوية الثانية. تسلط المسرحية الضوء على مخاطر السعي إلى تمكين المر أة من خلال تبني القيم الذكورية، و اعتماد أيديولوجية نسوية منمحورة حول الذات، مناهضة للأسرة ومعادية للرجل و لا تعبأ بمعاناة النساء المهمشات. يتقصى البحث استقاب شخصيات المسرحية على أساس الجنس أو العرق أو الطبقة أو الدين،



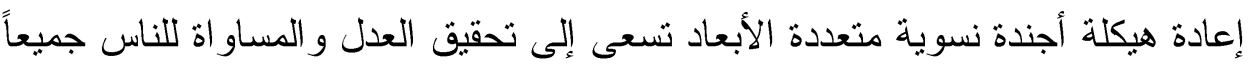
على اختلافهم، وتؤكد أن النجاح الوظيفي و الأسري للمر أة لا يستبعد أحدهما الآخر . 


\section{Futility of Feminist Aspirations in Caryl Churchill's Top Girls: A Postfeminist Reading}

Dr. Marwa Ramadan

Lecturer in English Literature

Faculty of Arts

Zagazig University

\section{Introduction: From Feminism to Postfeminism}

The core of feminist theory is gender equality. Feminists may disagree on many things but they unequivocally agree that the main goal of feminism is eradicating a centuries-long gender stratification, established by patriarchal ideology and promoted by laws and cultural norms that result in disparities of power and rights. Even though gender equality is still a dream deferred for many women in many parts of the world, the feminist movement that dates back to almost a century and a half ago has gone a long way in the struggle to dismantle patriarchy and enable women to explore their full potentials as equal human beings. Many aspects of women life, ranging from culture to law, have been relatively changed, thanks to the efforts of the suffragettes of the nineteenth century, the 1960s and 1970s second-wave campaigners for women's legal rights and the 1990s third-wave struggle to ensure equality for all women regardless of their race or class. Contemporary feminists are still striving to maintain a de facto incorporation of women's rights into the social, cultural, political, and economic arenas.

Despite the accomplishments of the movement, feminism as a concept has acquired certain ambivalence to the extent that many women today refuse to categorize themselves as feminists. The widespread appeal of social media campaigns such as "Women Against Feminism" demonstrates how the term sounds too radical, aggressive, and limiting for a considerable number of women. "For women of my generation," the American writer Rene Denfeld writes in The New Victorians (1995), "feminism has become as confining as what it pretends to combat" (5). She quotes numerous

\section{ELLS Vol.8 No.I}

(237)

December 2017 
Futility of Feminist Aspirations in Caryl Churchill's Top Girls: A

Postfeminist Reading

polls showing that though "American women of all ages overwhelmingly support feminist ideals ... they largely avoid calling themselves feminists and in many ways have abandoned the movement - even though most feel there is still work to be done" (3).

Some feminist critics have developed a backlash theory to explain women's alienation from feminism. According to Rhonda Hammer, a backlash against feminism "erupted in the 1980s," "became more firmly established in the 1990s," and "continues to escalate and proliferate" in the new millennium (24). The first to establish the backlash theory was Suzan Faludi in her book Backlash (1991) — where she asserts the existence of "a powerful counterassault on women's rights, a backlash, an attempt to retract the handful of small and hard-won victories that the feminist movement did manage to win for women" (9-10). As a result, Mary Luckhurst states, "western constructions of feminism have been alarmingly debased as an aggressive historical phenomenon despite continuing inequality, prejudice, sexism, and in some cultures, the violent repression and censorship of women" ("The Drama of Terrors").

The negative connotations feminism has acquired can be attributed to the multiplicity and diversity of feminist voices. As Jill Dolan asserts, feminism takes varied routes to "redress the fact of male dominance," and hence "feminism has in fact given way more precisely to feminisms" (3). I personally adopt bell hooks' conceptualization of the term in her book Ain't I a Woman': "to be 'feminist' in any authentic sense of the term is to want for all people, female and male, liberation from sexist role patterns, domination, and oppression" (195). Such approach to feminism seeks freedom from oppression for all people regardless of their

\footnotetext{
${ }^{1}$ bell hooks (born Gloria Jean Watkins) insists on writing her pen name in lowercase letters as a sign of her rejection of established ideology.
}

\section{ELLS Vol.8 No.I (238) December 2017}




\section{Dr. Marwa Ramadan}

gender, race, or class. For many critics of the movement-including established feminists - not all feminists seek that goal and not all forms of feminism are beneficial, even to women themselves, as some have blown way out of proportion in their struggle against the systematic forms of oppression. "I am a feminist who does not like what feminism has become," so declares Christina Hoff Sommers in her critique of what she calls "gender feminists" who blur the line between feminism and gender war (18). Likewise, Naomi Wolf excoriates gynocentric radical feminism for developing "maladaptive attitudes" - such as misandry and anti-femininitythat have opened a "breach ... between millions of women and the movement to secure their rights" (xxvi).

In one sense, postfeminism appeared as a reaction against "the wrong turn" some strands of feminism have taken. The term was First coined by Susan Bolotin in her 1982 article "Voices of the Post-Feminist Generation" to refer to the younger generation of women who "disavowed a connection with feminism while praising its political effects." Postfeminism, however, did not appear as a critical discourse until the 1990s. The term was then evoked by the media to describe such texts as Naomi Wolf's Fire with Fire (1993), Kate Roiphe's The Morning After (1993), Christina Hoff Sommers' Who Stole Feminism (1994), Rene Denfeld's The New Victorians (1995), and Cathy Young's Ceasefire!: Why Men and Women Must Join Forces to Achieve True Equality (1999). Though generally supportive of feminism, such writers declare their antagonism towards some of its classical tenets. Their primary target of criticism is second-wave feminism with its ethnocentrism, essentialism, arbitrary disregard of difference as well as its degrading attitude towards femininity, maternity, domesticity, and family life. Theirs is an equity feminism holding simply that women, though different from men, are human beings and therefore entitled to equal rights. Pro-women but not anti-men, postfeminists see misandry and radical separatist views that deem man as the enemy as sexist rather than feminist (Sommers 8). 
Futility of Feminist Aspirations in Caryl Churchill's Top Girls: A

Postfeminist Reading

Postfeminists seek women empowerment in all spheres of life and oppose perpetuating the image of women as patriarchy victims. Naomi Wolf, for instance, rejects what she calls "victim feminism" that assumes "universal female goodness and powerlessness and male evil." She describes such idea as "obsolete," arguing that "[f]emale psychology and the conditions of women's lives have been transformed enough so that it is no longer possible to pretend that the impulses to dominate, aggress, or sexually exploit others are 'male' urges alone." For Wolf, "[i]t is both empowering and moral for women to look honestly at the "dark side' within them, emerging now into light" (xxvii). Because of their criticism of leading feminist trends, postfeminists have been at times ostracized by the movement and accused of being reactionary antifeminists set to attack a broad range of feminist theory and practice. In Rhonda Hammer's view, those so-called postfeminists are "impersonator[s]" and "pseudofeminists" who assume "the guise of feminism in order to attack its most emancipatory tenets and politics and are thus part of the backlash against feminism itself" (23).

The term "postfeminism" is thus overloaded with different and sometimes conflicting meanings. Rosalind Gill notes that it "has become one of the most important and contested terms in the lexicon of feminist cultural analysis," used variously and contradictorily to signal either a theoretical break with second-wave feminism, a historical shift to a third wave, a "backlash" or "a regressive political stance" (147). Depending on whom one asks, postfeminism denotes either an opposition to feminism or an evolution to a new phase of feminist thought. Such "unresolvedand possibly irresolvable - debate," Sarah Gamble argues, "leaves postfeminism poised between two impulses, simultaneously forging forward and falling back" (62). According to Amanda Lotz, "Scholars often use the term to demarcate changes in representations of women and feminist discourses" (106).

ELLS Vol.8 No.I (240) December 2017 


\section{Dr. Marwa Ramadan}

Within the sphere of academic paradigms, Postfeminism "can be located on the crossroads between postmodernism, poststructuralism, and postcolonialism. The link is obvious since all paradigms are concerned with breaking through binary thinking" (Adriaens). Postfeminism particularly critiques the binary constructions set by second-wave feminism such as man/woman, feminism/femininity, domesticity/career. Opposing what Stephane Genz refers to as "the monolithic conception of "woman" or the fixed female identity postulated by second-wave feminism (337), postfeminists focus on difference, relativism, and hybridity. In Fien Adriaens' words, "Postfeminism pleads that every woman must recognize her own personal mix of identities." It is a pluralistic non-hegemonic discourse giving voice to a neoliberal approach towards femininity and gender relations, and subsuming the core notions of third-wave feminism, womanism, and postcolonial feminism with regard to the rights of marginalized women, women of color as well as women belonging to non-western cultures. As Georgina Murray puts it, postfeminism "facilitates a broad-based, pluralistic conception of the application of feminism" (39).

\section{Caryl Churchill's Top Girls as a Postfeminist Text}

Since her first feminist play Objection to Sex and Violence (1974), feminist struggles have been amply dramatized in Caryl Churchill's works. The conflicts portrayed in her drama and her own personal life as a wife and mother testify, however, that she doesn't embrace all forms of feminism. In fact, Churchill is a dramatist who defies categorization. While some critics see her as an ardent feminist, others put her among "an established, feminist generation of playwrights" who "were moving away from feminism, or even joining the anti-feminist backlash" (Aston xvii). Technically speaking, Churchill cannot be designated with one single style. Her experimentation with style and rejection of realistic modes and conventional dramatic forms-concurrent with her sociopolitical criticism and questioning of traditional power relations imposed by

\section{ELLS Vol.8 No.I (241) December 2017}


Futility of Feminist Aspirations in Caryl Churchill's Top Girls: A

Postfeminist Reading

those in authority - relate her to those playwrights who changed the face of British theatre during the second half of the twentieth century such as Harold Pinter, Tom Stoppard, Edward Bond, Howard Brenton, David Hare and Sarah Kane.

Churchill's Top Girls explains women oppression in terms of a complex intersection of gender, race, class, and ideology. It refutes, in addition, the dominant feminist discourses related to family, motherhood, abortion, and man-woman relationship based on binary opposition. I accordingly propose that Top Girls-written between 1980 and 1982 - can be read as a postfeminist text with early third wave sensibilities. I thus affirm a suggestive, but undeveloped, passing remark made by Graham Saunders in an article about Sarah Kane titled "Sarah Kane: Cool Britannia's Reluctant Feminist." In this article, Saunders notes in passing that, with its criticism of feminism failures, Top Girls anticipated "the specter of postfeminism" (209).

While in her earlier plays, like Vinegar Tom (1976) and Cloud Nine (1979), Churchill attacks the oppression that has been exercised upon women throughout history, in Top Girls she targets what she perceives as wrong and futile ways of dealing with that oppression. That is why, as Mary Luckhurst states, "Top Girls has been Caryl Churchill's most celebrated drama but its reception has never been straightforward" ("The Drama of Terrors"). Churchill juxtaposes historical and contemporary female characters, public and private worlds, domestic and working scenes with an aim to explore what she sees as destructive forms of feminism with pernicious influence on women and society. The play portrays its main character, Marlene, reaching a position of power in a maledominated environment at the expense of almost everybody around her-including her daughter and her sister. Top Girls seems to pose questions such as: what is more important for women, motherhood and family or career? Should it always be a binary opposition between "the angel in the house" and the self-centered feminist?

ELLS Vol.8 No.I (242) December 2017




\section{Dr. Marwa Ramadan}

Are individual stories of women empowerment enough to say that feminism has achieved its goals? Is it really "empowerment" when it ignores marginalized women who are not high-flyers or when it dictates the "masculinization" of women and suppression of their femininity? Such questions put in front of the audience in Top Girls still represent a challenge for many women, almost four decades after the play was written.

Events in Top Girls take place in Britain during the early 1980s. By that time second-wave feminism had had its profound stamp on the lives of women with its probing of the issues of family, women's employment, motherhood, sexuality and bodily autonomy. $40 \%$ of all working force were then women (Reskin 261). More women were getting good education and better access to top jobs than ever before in the history of Great Britain; they started to be viewed not only in terms of their reproductive system but as integral individuals with equal professional rights. On the other hand, marriage rates "fell to historically low levels" (Thane). Family life was no longer a priority for many of those women who decided to pursue careers, putting into practice Simone de Beauvoir's mantra in The Second Sex (1949): "It is through gainful employment that woman has traversed most of the distance that separated her from the male; and nothing else can guarantee her liberty in practice" (641).

On the political scene of 1980s Britain, Margaret Thatcher was the Prime Minister. Political power being held by Thatcher and official Royal position by Queen Elizabeth II resulted in what seemed to be a female rule over Britain that lasted for about twenty years. While that was a triumph for those women who endorsed the concept of "superwoman" based on Thatcher's figure as an "Iron Lady" and a thriving self-made career woman, Caryl Churchill did not support Thatcher and the capitalistic reforms that were implemented in Britain at her time. Top Girls shows that Churchill leans towards socialist feminism which proclaims that "capitalism, in addition to patriarchy, or the systems of male dominance, 
Futility of Feminist Aspirations in Caryl Churchill's Top Girls: A

Postfeminist Reading

contributes to the oppression of women" (Gimenez 13). She believes that although Thatcher was a woman herself, she worsened the life of women. "[T] hings have got much worse for women under Thatcher," she declares in a 1987 interview (Betsko and Koenig 77). Supporting Churchill's view in an article titled "Margaret Thatcher was no feminist," Hadley Freeman writes:

Thatcher can't really be seen as "a warrior in the sex war," let alone as "the ultimate women's libber." Far from "smashing the glass ceiling," she was the aberration, the one who got through and then pulled the ladder up right after her ... Thatcher is one of the clearest examples of the fact that a successful woman doesn't always mean a step forward for women.

Though the economy was robust and favorable for business at Thatcher's time, she was unpopular with the working class due to her adoption of radical right-wing practices; she reduced the power of trade unions, made cuts to social programs and privatized the major industries, which produced further class division and raised the unemployment rate. For working class women, she was of their gender, but she played by men's rules based on power and domination. Thatcher was yet a role model for Marlene who leaves her working class origin behind and goes for a successful career at the expense of her motherhood and personal life. She seems to be seduced by Thatcher's public success while failing to recognize the wife and mother of two children in this historical figure. Marlene may appear to be an epitome of feminist success, but her achievement is only individual; she is a top girl who has money and power, but she is only one of a few top girls occupying management positions. On the other hand, her sister, Joyce, who works many hours at a cleaning position and lives poorly as a result of Thatcher's reforms, represents the working class women of the period. It is argued that such dichotomy pinpoints "the extent to which second wave feminists were buying into Thatcher ideology to

ELLS Vol.8 No.I (244) December 2017




\section{Dr. Marwa Ramadan}

the detriment of a variety of real women" (Aston and Reinelt 14). The following conversation between Marlene and Joyce reveals their polarization along partisan and economic lines:

MARLENE. I think the eighties are going to be stupendous.

JOYCE. Who for?

MARLENE. For me. I think I'm going up up up.

JOYCE. Oh for you. Yes, I'm sure they will.

MARLENE. And for the country, come to that. Get the economy back on its feet ... She's a tough lady, Maggie.

JOYCE. You voted for them, did you?

MARLENE. needs to stop whining. Monetarism is not stupid ... It takes time, determination. No more slop.

JOYCE. Well I think they're filthy bastards. (83-^4; act III)

With its all-female cast and delineation of the achievements of famous women from history and that of Marlene as a top girl, the play primarily appears to celebrate feminist success, but it turns to be posing the question: what kind of success is that? This question crystallizes from the first act, which stands within the Brechtian epic structure of the play as a commentary on all the issues explored later. Transcending time and space boundaries, this opening act features Marlene-who has just got a promotion to a managing partner in an employment agency named "Top Girls"- -hosting a London restaurant dinner party with five peculiar women from the past. Some of them are real historical figures, while others are drawn from mythology, art, or literature. In spite of belonging to different cultures and social strata, these heterogeneous women have all lived in milieus that promote a male-based power structure and a derogative definition of the female gender; each has experienced some sort of oppression simply for being a woman. All of them have nonetheless achieved some sort of success. 
Futility of Feminist Aspirations in Caryl Churchill's Top Girls: A

Postfeminist Reading

Isabella Bird-a Victorian traveler with a bold spirit who traveled extensively around the world between the ages of forty and seventy - defies the typical image of an ordinary nineteenth-century woman confined to the domestic sphere. The legendary Pope Joan is believed to have been Pope in the ninth century, being the only woman ordained as Pope in the history of Christianity. Another guest from Japan, Lady Nijo, was a thirteenth-century concubine of an Emperor but eventually became a Buddhist nun who traveled the country on foot. In spite of her unfortunate circumstances as a woman who fell victim to the historical commoditization of the female body, her travels reflect a hopeful spirit full of determination and perception of new prospects. Patient Griselda-a folkloric character portrayed in Chaucer's Canterbury Tales-is another example of women facing adversity with fortitude. A poor girl married to a Marquis who cruelly and almost abnormally tests her fidelity, she finally gets him to relent through showing extreme patience and devotion. The last guest in Marlene's party is the folkloric Dull Gret, the subject of a painting by Flemish artist Pieter Bruegel in which a woman wearing an apron and armor and carrying a sword leads an army of women through hell to fight the devils.

Marlene's celebrating toast - “we've all come a long way. To our courage and the way we changed our lives and our extraordinary achievements" (13; Act I) - seemingly indicates that the feminist success of these women is the focus of Act I, but Churchill instead highlights the ironies of their success, the cost of their achievements, and the ultimate failure of their feminist ambitions. Notably, Marlene and her guests do not have a sense of sisterhood or empathy with their gender as a whole. As they are eating, drinking, and talking during the party, sharing their life stories with their upsides and downsides, they seem to be a unanimous ensemble of characters. Guest speeches, however, often overlap in confusing dialogues that bear the mark of Churchill's postmodern drama.

ELLS Vol.8 No.I (246) December 2017


Characters talk simultaneously and interrupt each other continually, which creates a growing tension and a sense of competition between them as each tries to reveal the details of her incredible life without any reference to other guests of the party. All of them are narcissistically self-absorbed, harboring the belief that the life of one individual is more important than the lives of others. Employing overlapping speech instead of the traditional dialogue structure helps Churchill portray them as "terrible egotists," "less a community than a group of competitors" (Brown 5).

As these six women are polarized by class, race, and religion, gender issues in the play are closely associated with other economic and cultural parameters that affect the relationships among the characters who reveal an obvious intolerance of otherness. The parochial snobbery of Isabella Bird, for instance, is manifested in her proud declaration that she is "of course a member of the Church of England" (5; Act I). Her intolerance towards Oriental cultures and religions other than Christianity is reflected in her disdain of Lady Nijo to whom she says blamefully: "I tried to understand Buddhism ... just filled me with the most profound melancholy." She condemns what she deems to be "barbaric practices in the east among the lower classes" (6; Act I). The "lower classes" of whom Isabella speaks contemptuously are completely out of focus for Marlene and her guests whose individual accomplishments are beyond the reach of the majority of women of their times. Set against the presence of these "top girls" who constantly speak on top of each other is the neglected waitress who serves them in complete silence, symbolizing the predicament of downtrodden women who do not have a voice in mainstream feminism which ignores race-and class-related oppression of women (Vineet 172). Of such women bell hooks writes in Feminist Theory: From Margin to Center (1984): "Women in lower class and poor groups ... would not have defined women's liberation as women gaining social equality with men since they are continually reminded in their

\section{$\begin{array}{lllll}\text { ELLS Vol.8 No.I (247) December } 2017 & \end{array}$}


Futility of Feminist Aspirations in Caryl Churchill's Top Girls: A

Postfeminist Reading

everyday lives that all women do not share a common social status" (19).

Another irony Churchill highlights in the success stories of Marlene and her guests is that, in their revolt against patriarchy and male oppression, these women have finally found themselves either imitating men or submitting to them. Janet Brown regards them as "powerless pawns of the patriarchy" despite "their adventure, their privilege, and their visibility to history" (105). The only exception is Dull Gret who stands as a symbol of women solidarity; having given "them devils such a beating," she is able to defy the powers of oppression symbolized by the devils through collective action with her female neighbors (28; Act I). Isabella, Pope Joan, and Marlene had to suppress their femininity and adopt male values in order to achieve success. Isabella initially asserts that she "always travelled as a lady and repudiated strongly any suggestion in the press that [she] was other than feminine" (8; Act I), but she finally dissociated herself from her femininity declaring that she "cannot and will not live the life of a lady" (26; Act I). Pope Joan also had to dissociate herself from her female body and disguise from an early age as a boy to be able to pursue her dream of theological learning at a time when women were not allowed into libraries. Only when love awakened her female self, an unexpected pregnancy disclosed her as a woman and therefore unfit to be Pope because "Women, children and lunatics can't be Pope" (15; Act I). As for Marlene, she had to bridle her maternal instinct, aborting several babies and abandoning her daughter in order to reach her top position.

While Marlene, Isabella, and Joan discarded their femininity to pursue their dreams, Patient Griselda and Lady Nijo adhered to what Christopher Innes calls the "archetypal feminine qualities" of conformity and submission in order to survive in their maledominated milieus (518). Showing unquestioning devotion to her powerful husband, believing that she "must always obey him in everything" (21; Act I), Griselda is an emblem of the obedient wife.

ELLS Vol.8 No.I (248) December 2017




\section{Dr. Marwa Ramadan}

She complied even with his most cruel and unreasonable orders including giving up the dearest thing for a mother-her childrenjust to gain his trust. Like Griselda, Nijo yielded to the patriarchal system; for the first half of her life she submitted to the emperor as a courtesan, and for the second half she submitted to the will of her father who wanted her to be a nun. The only act of rebellion of which she is extremely proud and eager to relate is once beating the Emperor - the symbol of patriarchal power-for degrading her in front of his attendants: "I had hit him with a stick. Yes, I hit him with a stick" (27; Act I). Her rebellion is only temporary. Having lost favor with the Emperor, she decided to follow the advice of her father: "serve His Majesty, be respectful, if you lose his favor, enter holy orders" (3; Act I). Her decision to become a nun was thus no more than a traditional act of obedience to one's father, not a matter of spiritual inspiration or a willing act of repentance.

The cheerful mood at the beginning of the party turns to a tone of regret and sadness as the guests reminisce about their past achievements. Marlene asks bitterly, "Oh God, why are we all so miserable?" (18; Act I). They know that they paid something significant for their success. Lady Nijo's and Griselda's children were taken away from them. Pope Joan was stoned to death together with her child. Though she declares that she found married life a "drudgery" and detested domesticity as exhausting to her "emotional reserves" (11, 25; Act I), Isabella Bird admits she experienced great loneliness as she could not settle to have a family. As Churchill puts it in an interview: "What I was intending to do was make it first look as though it was celebrating the achievements of women and then ... ask what kind of achievement is that?" (Betsko and Koeing 82). Marlene is the vessel into which Churchill puts her criticism of the limitations of the women movement. In Act II and III, she takes the audience from the historical context of Act I to Marlene's present milieu, featuring her work vs. her family life. A highly-competitive work environment-where women seek individual success by adopting masculine methods-is contrasted 
Futility of Feminist Aspirations in Caryl Churchill's Top Girls: A

Postfeminist Reading

with the domestic space with questions related to family, motherhood, abandoned children, and costs of women career success.

At work, Marlene is shown with her colleagues, Win and Nell, doing their daily jobs and conducting interviews with job applicants. They are extremely competitive with each other. While she congratulates Marlene on her promotion, Nell openly says that she would like to be in Marlene's place as she does not like "coming second" (50; Act II, Sc. 3 ). Nell's wish affirms what Janelle Reinelt refers to as "the difficulty of women bonding with each other in a competitive economic climate of the zero-sum game, where any advance of one takes something away from another, and where mistrust and lack of understanding create rifts among women" (31). In their search for economic and professional advancement, Marlene and her fellow "top girls" tend to mimic the behavior of men in the workplace, although they exhibit some sort of misandry mostly reflected in their talk about their male colleague, Howard. The latter's heart attack provokes no empathetic response from any of them except Win's words, 'Lucky he didn't get the job if that's what his health's like" (66; Act II, Sc. 3). They appear in the play on the verge of femininity and masculinity. Marlene, in particular, believes that she has to let go of her feminine essence to be able to compete for promotion. "Howard thinks because he's a fella the job was his as of right. Our Marlene's got far more balls than Howard," says Nell (46; Act II, Sc. 3). Marlene's growing masculinity is thus referred to as a "metaphoric gender transformation" (Vineet 175). Her usage of harsh, unsympathetic language leads Mrs. Kidd, Howard's wife, to tell her, "You're one of those ballbreakers, that's what you are. You'll end up ... miserable and lonely. You're not natural" (59; Act II, Sc. 3).

With the help of interviews that Marlene and her colleagues have with job applicants who are also women, Churchill highlights how these "top girls" believe that, in their pursuit of materialistic

ELLS Vol.8 No.I (250) December 2017




\section{Dr. Marwa Ramadan}

success, they have to give up the emotional qualities traditionally associated with women like compassion, care, empathy, and ability to nurture. Reflecting on such tendency prevailing in contemporary society, Megan Dalla-Camina contends that many "female role models" today are "just another version of a man, sometimes even more masculine." In an interview with Shona, a tough girl who aims high, Nell advises her to have "the guts to push through to a closing situation. They [the employers] think we're [women] too nice. They think we listen to the buyer's doubts. They think we consider his needs and feelings" (61; Act II, Sc. 3). Shona, who is obsessed with the concept of "superwoman," retorts saying: "I never consider people's feelings and I'm not very nice" (61; Act II, Sc. 3).

Epitomizing second-wave feminism, these women try to dismiss their femininity. At the core of second-wave thought, Fien Adriaens maintains, is "the idea that femininity and feminism are oppositional, mutually exclusive and that the adoption of one of these identities (feminine or feminist) can only be achieved at the expense of the other." Struggling for equality, second-wave feminists assert their basic similarity with men and deny any innate psychological difference between the two sexes (Vasile 237-38; Tandon 41-44). They maintain that if such a difference does exist, it is due to social construction and cultural conditioning, reiterating Simone de Beauvoir's argument in The Second Sex: "one is not born, but rather becomes, a woman" whose identity, values, and roles are defined by others (273). According to this argument which has instigated an internal debate among feminists, femininity is not an inherent part of the female identity but rather imposed by society.

Conversely, this assumption is refuted by postfeminists who accentuate that men and women are equal but not identical and hold femininity (articulated physically or emotionally) as a key signifier of women's identity. In Stephanie Genz's words, Postfeminism "reevaluates the tension that existed between feminism and femininity," as it creates "a link between previously opposed alternatives, carving out a new subjective space for women, 
Futility of Feminist Aspirations in Caryl Churchill's Top Girls: A

Postfeminist Reading

allowing them to be feminine and feminist at the same time without losing their integrity or being relegated to the position of passive dupes (334). Such tension provides the main trigger of action and cause of conflict in Top Girls. Believing that any trace of femininity or emotional tenderness conflicts with their female power, Marlene and her female colleagues have become extremely materialistic, self-centered, cold, and insensitive to the feelings of others; they are pushy and aggressive; they do not forget mistakes or tolerate weakness.

Ruthlessly competitive with no sisterly concern for other women, these women have veritably created a hierarchal power structure similar to the patriarchal one that has oppressed women for so long. Seeking individual power while neglecting powerless women, they virtually promote patriarchy instead of fighting against it as they do not distinguish between what bell hooks calls "power as domination and control over others and power that is creative and life-affirming" (Feminist Theory 84). For hooks, power linked to "domination and control" is the "form of power that has surfaced in feminist organizations, disrupting and corrupting feminist movement" (Feminist Theory 87). Marlene's offer to Jeanine, one of the applicants, a job that is going to make her "at the top" with other girls being "underneath [her]" (32; Act II, Sc. 1), supports Phyllis Chesler and Emily Goodman's argument in Women, Money, and Power that women rising to power "might just imitate men," turning in the process into "oppressors of other people, including other women" (255). The women-only cast in Top Girls is of paramount importance in this respect. It may be seen as a feminist stance that aims at empowering women and excluding men. Nevertheless, in the context of the play-which does not include an overt attack on men but on women's internalization of men's standards - such cast which excludes men can also be interpreted as a means to highlight the oppression exerted on women by fellow women as a result of copying the patriarchal rules.

ELLS Vol.8 No.I

(252) December 2017 


\section{Dr. Marwa Ramadan}

Through their speech, the "top girls" reveal their attitude toward family life. Nell dates different men, one of whom proposed to her, but she will not accept it as she does not want to "play house" (48; Act II, Sc.3). Jeanine is planning to get married, and so Marlene presupposes that she does not have long-term goals. She suggests that Jeanine hides her engagement:

MARLENE. Does that mean you don't want a longterm job, Jeanine?

JEANINE. I might do.

MARLENE. Because where do the prospects come in?

No kids for a bit?

JEANINE. Oh no, not kids, not yet.

MARLENE. So you won't tell them you're getting married?

JEANINE. Had I better not?

MARLENE. It would probably help.

JEANINE. I'm not wearing a ring. We thought we wouldn't spend on a ring.

MARLENE. Saves taking it off.

JEANINE. I wouldn't take it off. (31; Act II, Sc. 1)

Through such episodic dialogues, Churchill exposes biases against women in working life as well as limitations for women created by second-wave discourses on marriage and motherhood. One of these biases is that married women cannot be successful career-wise. In the 1980s, many employers refrained from hiring married women because of the risks of them getting pregnant and leaving the job. It was a great achievement that women finally became accepted as equal competitors in the workplace. However, social structure was built in a way in which a woman had to choose between career and family - a choice men did not have to make. For their part, secondwave feminists sought a transformation of women mentality to embrace career success instead of marriage and family life. Patriarchy was for them institutionalized in the nuclear family 
Futility of Feminist Aspirations in Caryl Churchill's Top Girls: A

Postfeminist Reading

system based on unequal division of domestic labor that rests on assumptions of women's "natural" place.

From the early days of second-wave feminism, Lauri Umansky records, the family "had to be understood as a key socializing institution of an entire social order bent upon breaking the human spirit" (25). In The Feminine Mystique (1963), Betty Friedan condemns nuclear family life as a waste of women potentials and a source of women degradation idealized by mainstream media (22-23). That "marriage constitutes slavery for women" was an idea circulated by several second-wave feminists following Friedan (Cronan 219). In conjunction with the critique of the nuclear family occurred a negative discourse on motherhood as a restriction on women's liberation (Hughes 54), "a social mandate, an oppressive institution, a compromise of a woman's independence, and a surrender to the half-human destiny that biology supposedly decrees to women" (Umansky 2). The boldest of such critiques is perhaps Shulamith Firestone's The Dialectic of Sex (1970) - a blueprint for radical feminism - which calls for the utter abolition of the nuclear family in order to promote a postpatriarchal society where women's reproductive role as child bearer and rearing mother is replaced by artificial means of gestation and child rearing social units (11).

Though later second-wave voices such as Carol Gilligan, Sara Ruddick, and Anna Coote have moved towards a more positive valorization of motherhood, the high-flyer heroine in Churchill's play adopts the archetypal anti-family and anti-motherhood attitude. Marlene abstains from marriage and devotes her whole life to no one but herself. She had a couple of abortions as she does not want her life to be restricted by children. A conversation with Pope Joan in Act I, in which she says that Joan should have aborted the baby that caused hurdles to her career as a Pope, reveals Marlene's hardboiled attitude towards maternity: 


\section{Dr. Marwa Ramadan}

JOAN. Wouldn't that be a worse sin than having it? But a Pope with a child was about as bad as possible

MARLENE. Other Popes had children, surely.

JOAN. They didn't give birth to them.

NIJO. Well you were a woman.

JOAN. Exactly and I shouldn't have been a woman. Women, children and lunatics can't be Pope.

MARLENE. So the only thing to do was to get rid of it. (15; Act I)

Getting rid of babies is a wiser choice for Marlene than taking responsibility for them. She exhibits motherism and loathing towards women who try to have it all-combining motherhood and professional work - as they remind her of her failure. That is reflected in pejorative statements such as, "I know a managing director who's got two children, she breastfeeds in the board room, she pays a hundred pounds a week on domestic help alone" (80; Act III). She is also judgmental of Griselda who received a reward for being a devoted wife. The same actress that plays Griselda in Act I plays Jeanine in Act II. Though Jeanine is about to get married, she still wants to have a successful career. She aims high, but Marlene does not believe that a loving wife can also be a pushy professional, and so offers her lower positions. In the characters of Griselda and Jeanine, Marlene faces her biggest challenge, the choice between domesticity and profession, a challenge which is very personal for Caryl Churchill who is at odds with second wave's definition of what is, or is not, good and right for women (Goodman 239).

Being a mother of three, a wife, and a writer, Churchill explores the limitations of the feminist ideology concerning marriage and motherhood proving that women can simultaneously be caring mothers, cultivate intimate relationships, and pursue highlevel careers, even though they may have to make sacrifices at certain points of their lives. During the 1960s, soon after she got married and through the next ten years, Churchill had to temporarily 
Futility of Feminist Aspirations in Caryl Churchill's Top Girls: A

Postfeminist Reading

stay at home to look after her children, but she didn't give up her career aspirations as she wrote radio and television plays in the meanwhile. Later, her husband took time off his lucrative law job at her request to take care of the kids, and the two began to divide domestic labor more equally, giving her more time to fulfill her career dreams (Luckhurst, Caryl Churchill 15). This reciprocal relationship testifies that true equality can best be achieved through a conscious cooperation between men and women.

Any such kind of sacrifice is unintelligible to Marlene whose callous attitude towards family is highlighted when her niece, Angie, comes to see her aunt in London. Marlene is not happy about Angie's arrival and keeps asking how long she will be staying with her. When Win tells her that Angie "is a nice kid," and wants to stay in London and work for Top Girls, Marlene answers, "She's a bit thick. She's a bit funny ... She's not going to make it" (66; Act II, Sc. 3). With her individualistic mindset, Marlene divides women into those who can play by men's rules and those who are "not going to make it" or do not have "what it takes" (86; act III). According to this division, marginalized women's position is even more complicated as they are oppressed by both men and high-flyer women. Top girls are few, while the majority of women could not, or do not want to, compete with men. The equality struggled for by feminists is thus not really reached as only a small group of women are qualified and willing to sacrifice their personal life in order to gain the privileges of a successful career, while other women do not practice any rights.

This dichotomy becomes clearer in act III which takes a step back in time; it depicts Marlene's arrival at her native town and meeting with her sister Joyce and her niece Angie, a year before the events in Act I and II. Sisters seem disconnected and alienated from each other. They have not seen each other for almost six years and do not know what was going on in each other's lives:

MARLENE. Have you seen Mother?

ELLS Vol.8 No.I (256) December 2017


JOYCE. Of course I've seen Mother.

MARLENE. I mean lately.

JOYCE. Of course I've seen her lately, I go every Thursday ...

MARLENE. How is your [Angie's] dad? Where is he tonight? Up the pub?

JOYCE. He moved out.

MARLENE. What? When did he? Just recently?

JOYCE. No, it must be three years ago. (73-74; Act III)

The dialogue between the two sisters acquaints the audience with Marlene's family background and the choices she has made to reach the high position she celebrates in Act I. Early in her life, she has decided to divorce herself from what she calls "fucking awful life" associated with her working class family (78; Act III). "I don't believe in class," she tells Joyce as she firmly believes that "[a]nyone can do anything" if they are competitive enough (86; Act III). She thus declares adamantly, "I hate the working class ... it doesn't exist anymore, it means lazy and stupid" (85; Act III). The sisters' conversation quickly turns into a quarrel as these two women are opposites on the economic, political, and social spectra. Joyce's suffering is deeply politicized in the play reflecting the social and political power structures of her society and asserting the feminist slogan "The Personal is Political." Unlike her sister, Joyce criticizes Thatcher's policies as suffocating for the poor, seeing her gender as irrelevant. She regards her as evil as Hitler: "What good's first woman if it's her? I suppose you'd have liked Hitler if he was a woman. Ms. Hitler. Got a lot done, Hitlerina" (84; Act III). Unlike her sister too, Joyce stayed in their hometown with her husband and daughter, feeling obliged as well to take care of their aging mother whom Marlene has not seen for years. Based on her own words, she was trapped by her family life:

MARLENE. You could have left ...

JOYCE. How could I have left?

\section{ELLS Vol.8 No.I}

(257)

December 2017 
Futility of Feminist Aspirations in Caryl Churchill's Top Girls: A

Postfeminist Reading

MARLENE. Did you want to?

JOYCE. I said how, how could I?

MARLENE. If you'd wanted to you'd have done it. (76; act III).

Near the end of the play, it is revealed that Marlene is the biological mother of Angie and that she chose to paralyze her maternal instinct and leave her illegitimate daughter to her sister so that she would be able to freely move out of her hometown and rapidly up the career ladder. Now, when she has reached heights in her profession, she is "so disconnected from any sense of being Angie's mother that she can barely conceal her dismay when her daughter walks into her office" (Luckhurst, "The Drama of Terrors"). As for Joyce, she has the feminist spirit which rejects oppression. Unlike her mother-who had submitted to an abusive alcoholic husband-Joyce abandoned her husband when she could no longer tolerate his controlling nature. Yet, she couldn't abandon the values of care and giving to the extent that she chose to sacrifice herself for the sake of Angie whose birth mother does not appreciate this sacrifice; Marlene openly accuses her sister of failure because of her preoccupation with family issues.

Marlene and Joyce are two extremes, highlighting the selfishness vs. selflessness dichotomy widely discussed by feminist theorists. They represent two archetypal female roles: the selfcentered career woman and the self-denying "angel in the house." Through these extremes, Churchill questions the definition of successful life for a woman. Can Marlene's life be called successful? Can Joyce's life be called successful? It is clear that they are both in a no-win situation; one is unfulfilled, and the other is lonely and miserable, which implies that sacrificing one of the two components - self or others - will not bring happiness. That is highlighted through the mother-daughter relationship between Marlene/Joyce and Angie. As Marlene had to give up Angie to Joyce in order to

ELLS Vol.8 No.I

(258)

December 2017 


\section{Dr. Marwa Ramadan}

pursue her career, her sister's life is a representation of what she would have become if she had stayed with her family.

Angie is thus a rift between two female archetypes. She is a burden and a representation of guilt for her biological mother, Marlene, and a host of lost opportunities for her aunt, Joyce. Angie's last word in the play_- "frightening" (87; Act 3) - possibly implies Churchill's vision of the future: the political future under monstrous capitalism; the future of sisterhood in a woman-versuswoman competitive environment; and, most importantly, the future of children whose mothers seek the rights of women but ignore the right of children, and whose fathers are completely out of the picture. Children, as Mary Luckhurst notes, "are far from safe in Churchill's worlds," which are "Beckettian in their darkness," as parents abandon and abuse, instead of nurture and protect, their offspring ("The Drama of Terrors").

Caryl Churchill is a socially-engaged playwright in search of an answer to how to transform society. To match form and content, she invests in Top Girls in an innovative style with extreme stylistic variations between the acts. She employs an episodic plot structure, historical references and a mixture of fantasy and reality, with an eye to transform the traditional outlook based on binarity. In Christopher Innes' words, "combining surreal fantasy with Shavian discussion, documentary case-histories, and naturalistic domestic drama (complete with kitchen sink and ironing-board), Top Girls breaks out of conventional methods of portraying life on the stage, and suggests new ways of seeing reality" (466). The structure of the play appears to be crooked, truncated and lacking unity, paralleling the path of its main characters whose lives are crooked and lack any sense of balance. Churchill places the confrontation scene between Marlene and Joyce at the end of the play, although its events occur earlier. This nonlinear episodic structure where events are dramatized out of chronological order is a characteristic of the Brechtian dialectical theatre by which Churchill is profoundly influenced and which is highly popular among feminist playwrights 
Futility of Feminist Aspirations in Caryl Churchill's Top Girls: A

Postfeminist Reading

who nurse the idea of an unconventional theatre creating a cultural climate for social change. Such dramatic construction helps Churchill to completely convey her message with the last scene of the play. What she wants to stick with the audience is not the success of Marlene, but the bleak and gruesome image of a daughter whose relationship with her mother has been severed and whose vision of the future is "frightening."

Referred to by Brecht as "non-Aristotelian drama," dialectical theatre helps to effect social transformation based on reason rather than emotion as it alienates the audience from the fictional reality of the stage and prevents their emotional involvement and over empathy with the character. The objectivity of the audience is also maintained in Top Girls through the dual-role technique, with actors playing more than one character. Through this doubling technique, the similarities between the historical female characters in Act I and their modern counterparts are highlighted, suggesting that the myriad forms of oppression against women as well as women's methods of fighting that oppression have not essentially altered. Marlene's colleague, Win, is doubled with Lady Nijo, as both personify the sexual objectification of women. Like Nijo who was exploited as a courtesan by the emperor and had secret affairs with two married men, Win dates a married man who takes her to his house when his wife is away and urges her to "lie down in the back of the car so the neighbours wouldn't see [her] go in" (49; Act II, Sc. 3). While Churchill attacks such objectification of the female body which has been a norm in patriarchal societies, she also seems to criticize, in the characters of Nijo and Win, those women who objectify themselves under the illusion of sexual liberation.

Another example of the dual-role technique is doubling Patient Griselda, the emblem of female obedience, with both Jeanine and Nell. With her willingness to obey her fiancé and let him determine her future, Jeanine appears to be an extension of

ELLS Vol.8 No.I (260) December 2017




\section{Dr. Marwa Ramadan}

Griselda despite the long centuries that separate them. Nell, on the other hand, is an independent career woman who avoids marriage and seeks power at work by ignoring her femininity and adopting masculine values. Doubling the strong-headed Nell with the submissive Griselda just like Jeanine reveals Churchill's intention to show both passive submission to male authority and fierce imitation of male values as two faces of the same surrender to patriarchy.

All the sets of doubling in Top Girls suggest the futility of the feminist aspirations of the characters involved due to misconceptions of what gender equality really means. The only doubling which gives hope in the future of feminism is that of Angie and Dull Gret. Angie is judged by Marlene as a thick funny girl who is "not going to make it." She is as "dull" as Dull Gret who, despite her seeming dullness and inability to actively participate in the conversation or talk as eloquently as the other women in Marlene's dinner party, is the one who is really able to defy the forces of oppression through women solidarity and collective action. Angie appears to be weak, but her sisterly friendship with Kit - who dreams to be a nuclear physicist - is a major source of strength in her life. Doubling Dull with Angie, Churchill gives hope for Angie and her likes to collectively resist both patriarchal tyranny and feminist misconceptions about equality, success, and empowerment.

\section{Conclusion}

Through deconstructing the so-called success of a career woman like Marlene, Caryl Churchill's Top Girls provides a critical reassessment of the women's movement and its limitations. A thorough reading of Top Girls reveals the prevalence of certain perspectives that characterize the postfeminist theoretical standpoint, though it was written before the rise of postfeminism as a critical discourse. The play critiques the essentialism, disregard of difference, binary thinking and ideas on equality associated with second-wave feminism. Top Girls critiques as well second wave's

\section{ELLS Vol.8 No.I (261) December 2017}


Futility of Feminist Aspirations in Caryl Churchill's Top Girls: A

Postfeminist Reading

presumptions that femininity and feminism are oppositional and responsible motherhood and career success are mutually exclusive. It sheds light on the dangers of transgressing the mores of motherhood for the sake of the self as well as the dangers of selferasure for the sake of others. These two extremes are highlighted through the characters of Marlene, who gives up her baby to achieve professional success, and her sister Joyce, who gives herself up to look after that baby. By showing that both of them are miserable and unhappy, Churchill demonstrates the need for a third option through which women can felicitously harmonize family and professional life and achieve the delicate balance between self and others.

Anticipating both postfeminism and third-wave feminism, Top Girls calls for an inclusive feminist theory that takes into consideration the intersectionality of race, class, and gender and encourages the idea of sisterhood based on empathy, tolerance, and accepting of difference. The question posed is: is it a success for feminism when only a few women are empowered while others are neglected and left to strive under inequality? Addressing the failures of the second wave, the play opens up spaces for the articulation of alternative forms of feminism that seek equality for all people, no matter their race, class, abilities, or even gender. Top Girls thus endorses a restructuring of a multi-dimensional feminist agenda free from separationist ideology and exclusively self-centered ambitions. This phase of feminism in which equality is not polarized versus difference would be part of a postmodern ideology brought to British theatre by a number of playwrights among whom Caryl Churchill is a pioneer. 


\section{Works Cited}

Adriaens, Fien. "Postfeminism in Popular Culture: A Potential for Critical Resistance?" Politics and Culture, no. 4, 9 Nov. 2009, politicsandculture.org/2009/11/09/post-feminism-inpopular-culture-a-potential-for-critical-resistance. Accessed 6 Jan. 2017.

Aston, Elaine. Feminism and Theatre. Palgrave Macmillan, 2008.

Aston, Elaine, and Janelle Reinelt. "A Century in View: From Suffrage to the 1990s." The Cambridge Companion to Modern British Women Playwrights, edited by Elaine Aston and Janelle Reinelt, Cambridge University Press, 2000, pp. 120.

Betsko, Kathleen, and Rachel Koenig, editors. Interviews with Contemporary Women Playwrights. Beech Tree, 1987.

Bolotin, Susan. "Voices from the Post-Feminist Generation." The New York Times, 17 Oct. 1982, www.nytimes.com/1982/10/17/magazine/voices-from-thepost-feminist-generation. Accessed 20 Jan. 2017.

Brown, Janet. Taking Centre Stage: Feminism in Contemporary US Drama. Scarecrow Press, 1992.

Chesler, Phyllis, and Emily Goodman. Women, Money and Power. William Morrow, 1976.

Churchill, Caryl. Top Girls. Bloomsbury, 1982.

Cronan, Sheila. "Marriage." Radical Feminism, edited by Anne Koedt et al, Quadrangle/ The New York Times Book Company, 1973, pp. 213-21.

Dalla-Camina, Megan. "Are you Rejecting your Feminine Traits?" Psychology Today, 4 Apr. 2015, www.psychologytoday.com/blog/real-women/201504/areyou-rejecting-your-feminine-traits. Accessed 15 Mar. 2017.

De Beauvoir, Simone. The Second Sex. 1949. Translated by H. M. Parshley, Jonathan Cape, 1953, www.thinkphilosophy.org/uploads/6/1/0/9/6109978/simonede-beauvoir-the-second-sex-1.pdf. Accessed 12 Dec. 2016. 
Futility of Feminist Aspirations in Caryl Churchill's Top Girls: A

Postfeminist Reading

Denfeld, Rene. The New Victorians: A Young Woman's Challenge to the Old Feminist Order. Hachette Book Group, 1995.

Dolan, Jill. The Feminist Spectator as Critic. 1988. University of Michigan Press, 2012.

Faludi, Susan. Backlash: The Undeclared War Against American Women. 15th ed., Three Rivers Press, 2006.

Firestone, Shulamith. The Dialectic of Sex: The Case for Feminist Revolution.

Morrow, 1970 , teoriaevolutiva.files.wordpress.com/2013/10/firestoneshulamith-dialectic-sex-case-feminist-revolution.pdf. Accessed 15 Nov. 2016.

Freeman, Hadley. "Margaret Thatcher Was No Feminist." The Guardian, $\quad 9$ Apr. 2013, www.theguardian.com/commentisfree/2013/apr/09/margaretthatcher-no-feminist. Accessed 30 Feb. 2017.

Friedan, Betty. The Feminine Mystique. Norton, 1963, nationalhumanitiescenter.org/ows/seminars/tcentury/Feminin eMystique.pdf. Accessed 11 Nov. 2016.

Gamble, Sarah. "Growing Up Single: The Postfeminist Novel." Studies in the Literary Imagination, vol. 39, no. 2, Fall 2006, pp. 61-78. Questia, www.questia.com/library/journal/1G1172906651. Accessed 29 Nov. 2016.

Genz, Stephane. "Third Way/ve. The politics of postfeminism." Feminist Theory, vol. 7, no. 3, 2006, pp. 333-53, journals.sagepub.com/doi/pdf/10.1177/1464700106069040. Accessed 20 Dec. 2016.

Gill, Rosalind. "Postfeminist Media Culture: Elements of a Sensibility." European Journal of Cultural Studies, vol.10, no. 2, 2007, pp. 147-66, eprints.lse.ac.uk/2449/1/Postfeminist_media_culture_(LSER O).pdf. Accessed 10 Feb. 2017.

Gimenez, Martha E. "Capitalism and the Oppression of Women: Marx Revisited." Science and Society, vol. 69, no. 1, January

ELLS Vol.8 No.I (264) December 2017 
2005, pp. 11-32. Jstor, www.jstor.org/stable/40404227. Accessed 2 Feb. 2017.

Goodman, Lizbeth. Contemporary Feminist Theatres: To Each Her Own. Routledge, 1993.

Hammer, Rhonda. Antifeminism and Family Terrorism: A Critical Feminist Perspective. Rowman and Littlefield, 2002.

hooks, bell. Ain't I a Woman: Black Women and Feminism. Pluto Press, 1982.

---. Feminist Theory: From Margin to Center. South End Press, 1984.

Hughes, Christina. Women's Contemporary Lives: Within and Beyond the Mirror. Routledge, 2002. Questia, www.questia.com/library/108058746. Accessed 15 Mar. 2017.

Innes, Christopher. Modern British Drama: The Twentieth Century. Cambridge University Press, 2002.

Lotz, Amanda D. "Postfeminist Television Criticism: Rehabilitating Critical Terms and Identifying Postfeminist Attributes." Feminist Media Studies, vol. 1, no. 1, 2001, pp. 105-21, dx.doi.org/10.1080/14680770120042891. Accessed 14 Feb. 2016.

Luckhurst, Mary. Caryl Churchill. Routledge, 2015.

---. "Caryl Churchill and the Drama of Terrors." Out Of Joint, 30 Nov. 2011, www.outofjoint.co.uk/production/caryl-churchilland-the-drama-of-terrors. Accessed 11 Jan. 2017.

Murray, Georgina. "Agonize, Don't Organize: A Critique of Postfeminism." Current Sociology, vol. 45, no. 2, April 1997, pp. journals.sagepub.com/doi/abs/10.1177/001139297045002004 . Accessed 5 Jan. 2017.

Reinelt, Janelle. "On Feminist and Sexual Politics." The Cambridge Companion to Caryl Churchill, edited by Elaine Aston and Elin Diamond, Cambridge University Press, 2009, pp. 1835 . 
Futility of Feminist Aspirations in Caryl Churchill's Top Girls: A

Postfeminist Reading

Reskin, Barbara F. "Sex Segregation in the Workplace." Annual Review of Sociology, vol. 19, no. 1, 1993, pp. 241-70, www.annualreviews.org/doi/abs/10.1146/annurev.so.19.0801 93.001325. Accessed 22 Feb. 2017.

Saunders, Graham. "Sarah Kane: Cool Britannia's Reluctant Feminist." Thatcher and After: Margaret Thatcher and her Afterlife in Contemporary Culture, edited by Louisa Hadley and Elizabeth Ho, Palgrave Macmillan, 2010, pp. 199-220, link.springer.com/content/pdf/10.1057\%2F9780230283169 10.pdf. Accessed 12 Feb. 2017.

Sommers, Christina Hoff. Who Stole Feminism? How Women Have Betrayed Women. Simon and Schuster, 1994.

Tandon, Neeru. Feminism: A Paradigm Shift. Atlantic, 2008.

Thane, Pat. "Happy Families?: Realities of Family Life in Twentieth Century Britain." The Economic History Review, 27 Mar. 2014, www.ehs.org.uk/press/happy-families-realities-offamily-life-in-twentieth-century-britain. Accessed 11 Mar. 2017.

Umansky, Lauri. Motherhood Reconceived: Feminism and the Legacies of the Sixties. New York University Press, 1996.

Vasile, Georgiana. "The Female Voices in Caryl Churchill's Top Girls (1982): Sisters or Foes." Anagnorisis, no. 1, 2010, pp. 233-59, www.anagnorisis.es/pdfs/Georgiana Vasile.pdf. Accessed 14 Nov. 2016.

Vineet. "Caryl Churchill as a Feminist Playwright: A study of Five Plays." Dissertation, Maharishi Markandeshwar University, 2015, shodhganga.inflibnet.ac.in/handle/10603/38612. Accessed 3 Feb. 2016.

Wolf, Naomi. Fire with Fire: New Female Power and How it Will Change the Twenty-First Century. Vintage, 1993.

$\begin{array}{lllll}\text { ELLS Vol.8 No.I (266) December } 2017 & \end{array}$ 